\title{
Повногеномний пошук асоціацій у пацієнтів української популяції з акромегалією
}

\section{О.Т. Олексик,} Х.М. Щубелка,

\section{В.В. Волфсбергер}

Ужгородський національний університет, м. Ужгород

\begin{abstract}
Резюме. Гіпофіз-залежний надлишок СТГ може бути генетичним захворюванням (у літературі описано низку мутацій, які призводять до ізольованого надлишку гормону росту) або як симптом у складі синдромного захворювання. Мета - провести повногеномний пошук асоціацій геному пацієнтів з акромегалією для виявлення відомих мутацій у генах, асоційованих із даним захворюванням, і суміжних ділянках. Створити першу референтну геномну базу пацієнтів з акромегалією української популяції для подальшого вивчення причин виникнення цієї хвороби та впровадження персоніфікованого лікування згідно з генетичним профілем. Результати. Проведено повногеномний пошук асоціацій у геномі 5 хворих на акромегалію. Використана панель генотипування дозволила ідентифікувати 154 однонуклеотидні поліморфізми в генах, які були описані раніше як асоційовані з акромегалією. Один пацієнт виявився гетерозиготним за альтернативною алеллю (AG) OHП rs33927012 гена SDHB. Дана альтернативна алель $\epsilon$ надзвичайно рідкісною у світовій популяції (0,9\%, в європейській популяції - 2\%). Ії̈ описано як шкідливу двома аналітичними системами. Мутації гена SDHB призводять до структурних змін у білку SDH (сукцинілзалежна дегідрогеназа), який відіграє ключову роль у циклі Кребса та окисному фосфорилюванні. Даний ген $\epsilon$ тумор-супресор геном, і його мутації спричиняють ЗР синдром (акромегалія, феохромоцитома, парагангліома). Також знайдено мутації в генах SDHC, CDKN1B, унікальні для деяких пацієнтів даної вибірки. Висновки. Знайдено три екзонні загрозливі та потенційно шкідливі мутації в генах CDKN1B і SHDB, які виявляються в пацієнтів з ендокринними синдромами.
\end{abstract}

Ключові слова: акромегалія, геном, мутації.

\section{Вступ}

Соматичний ріст контролюється гормональною взаємодією між гіпоталамусом, гіпофізом і периферичними тканинами [1]. Гігантизм та акромегалія є рідкісними порушеннями, ви-

* Адреса для листування (Correspondence): ДУ «Інститут ендокринології та обміну речовин ім. В.П. Комісаренка НАМН України», вул. Вишгородська, 69, м. Київ, 04114, Україна. E-mail:zdovado@ukr.net

๑ О.Т. Олексик, Х.М. щубелка, В.В. Волфсбергер кликаними надмірною секрецією гормону росту - соматотропіну (СТГ) та/або його вторинного месенджера - інсуліноподібного чинника росту 1 (ІЧР-1). Гігантизм виникає тоді, коли надлишок СТГ або ІЧР-1 призводить до збільшення лінійного росту кісток, зазвичай до кінця пубертатного періоду та закриття епіфізарних зон росту, й характеризується розростанням 
коротких і плоских кісток і хрящів. У більшості випадків ці захворювання виникають унаслідок розвитку доброякісної СТГ-продукуючої аденоми гіпофіза (СТГПАГ). Захворюваність на гігантизм та акромегалію становить 8-11 випадків на 1 мільйон населення за 1 рік [2, 3]. Початок гігантизму в ранньому дитинстві та той факт, що пацієнти з гігантизмом та акромегалією часто мають схожі симптоми в родинах, дали підстави висунути гіпотезу, що гіпофіз-залежний надлишок СТГ може бути генетичним захворюванням. Дійсно, протягом останніх трьох десятиліть генетичні дослідження виявили низку генетичних дефектів, що призводять до гігантизму. Наразі відомо, що багато генів залучено до схильності до гігантизму або акромегалії, а також відомо просоматичні мутації в онкогенах або генах-супресорах пухлин, які регулюють основні сигнальні шляхи в клітинах СТГ-продукуючих аденом [4].

Ця група захворювань включає синдроми множинної ендокринної неоплазії 1-го та 4-го типів (MEN-1 і MEN-4), МакК'юна - Олбрайта (MAS), комплекс Карні (CNC), синдром 3Ps (парагангліома, феохромоцитома й аденома гіпофіза), спадкову ізольовану аденому гіпофіза (FIPA) та широко вивчається через дефекти генів, які кодують сукцинілдегідрогеназу $[5,6]$. Зокрема, нещодавно описано форми родинних і спорадичних акромегалії та гігантизму, викликані мікродуплікацією на хромосомі Хq26.3 розлад, який був названий «Х-зчепленим акрогігантизмом» (X-LAG). Існують чотири гени в дуплікованій ділянці ДНК. Один із них, $G P R 101$, кодує орфанний G-протеїн-зв'язаний рецептор, який зумовлює фенотипові зміни в маленьких дітей і ріст спорадичних аденом гіпофіза, що продукують гормон росту в деяких пацієнтів з акромегалією [7]. Мутація $G N A S-$ активуюча мутація в G-протеїн-стимулюючій субодиниці альфа (Gs $\alpha$ ) у статевих клітинах є несумісною з життям; ця ж мутація в соматичних клітинах веде до гігантизму за синдрому МакК'юна - Олбрайта та акромегалії за спорадичних СТГ-продукуючих аденом гіпофіза [8]. Мутації PRKAR1A, що призводять до збільшення сигнальної функції АМФ, як і мутації $G N A S$, викликають гігантизм або акромегалію в складі комплексу Карні, але їх ніколи не було описано за спорадичних СТГ-продукуючих аденом гіпофіза [9]. Мутації гена $M E N 1$ при- зводять до гігантизму та/або акромегалії в складі синдрому MEN-1, рідше - до спорадичної акромегалії [10]. Мутації в циклін-залежній кіназі 1B (CDKN1B) трапляються за синдрому MEN-4 [11].Інші CDKN, які є необхідними молекулами в регулюванні клітинного циклу, росту та проліферації, мутують зрідка за MEN1/MEN4-подібного синдромного гігантизму та/або акромегалії, але не в спорадичних СТГПАГ [12]. Пацієнти з родинною ізольованою СТГ-продукуючою аденомою гіпофіза (FIPA) також можуть мати як гігантизм, так i акромегалію; у них генетичний дефект виникає в арил-вуглеводневому рецептор-взаємодіючому білку (АIP) [5].

Проте є випадки, наразі генетично не ідентифіковані за допомогою сучасних методів. До них належать не лише синдромні випадки 3 підвищеною продукцією СТГ [13], але й спорадичний гігантизм i, звичайно, ізольовані випадки СТГ-продукуючих аденом гіпофі3а. Секвенування 50-UTR ділянки генів, які беруть участь у молекулярному патогенезі СТГПАГ, рутинно не проводиться, i, можливо, наукове товариство має розглянути доцільність цього типу дослідження для пацієнтів із гігантизмом або ранньою акромегалією, обтяженим анамнезом та/або іншими пухлинами, негативними щодо будь-яких відомих генетичних дефектів. По-друге, чинники транскрипції, мікроРНК та інші молекули, які можуть зв'язуватися 3 регуляторними елементами в 50 -UTR ділянці $C D K N 1 B$ або інших генів ( $G N A S, P R K A R 1 A$, $M E N 1, A I P$ тощо) де-факто є кандидатами на дефекти, що можуть бути причиною акромегалії. По-третє, лабораторні дослідження в пацієнтів із СТГПАГ, негативних щодо мутацій у відомих генах, дослідження цілого геному за допомогою порівняльної геномної гібридизації (CGH - молекулярний цитогенетичний метод аналізу повторів ДНК) може бути таким же корисним, як цілковите секвенування екзонів (WES). Наприклад, CGH було важливим для ідентифікації дефектів на X-хромосомі за синдрому X-LAG, тоді як WES не вдалося виявити причинний ген у цьому випадку [14].

Загалом описані в літературі гени, визначені як потенційно асоційовані з розвитком соматотропіном гіпофіза або комплексних синдромів із компонентом акромегалії, наведено в таблиці 1. 
Оригінальні дослідження

таблиця 1. Гени, визначені як потенційно асоційовані з розвитком соматотропіном гіпофіза або комплексних синдромів із компонентом акромегалії

\begin{tabular}{|c|c|c|c|c|c|}
\hline Ген & $\begin{array}{l}\text { Локація } \\
\text { гена }\end{array}$ & $\begin{array}{l}\text { Поширеність } \\
\text { серед пухлин } \\
\text { гіпофіза, \% }\end{array}$ & $\begin{array}{l}\text { Поширеність } \\
\text { за акромегалії }\end{array}$ & Фенотипові прояви & Патологія \\
\hline AIP & $11 q 13.3$ & 3,6 & $\begin{array}{l}\text { 50\% за гомогенних за FIPA } \\
\text { 4\% за спорадичних } \\
\text { соматотропіном }\end{array}$ & $\begin{array}{l}\text { Родинна ізольована пухлина } \\
\text { гіпофіза, молоді пацієнти; інвазійні } \\
\text { пухлини; гірша відповідь на аналоги } \\
\text { соматостатину }\end{array}$ & Соматотропінома \\
\hline MEN1 & $11 \mathrm{q} 13.1$ & $0,6-2,6$ & $1,2 \%$ & $\begin{array}{l}\text { Гіперпаратиреоз, аденоми гіпофіза, } \\
\text { підшлункової залози, APUD-системи } \\
\text { (MEN1) }\end{array}$ & Соматотропінома \\
\hline CDKN1B & $12 \mathrm{p} 13.1$ & Зрідка & Зрідка & $\begin{array}{l}\text { Гіперпаратиреоз, аденоми гіпофіза, } \\
\text { підшлункової залози (MEN4) }\end{array}$ & Соматотропінома \\
\hline PRKAR1A & $17 q 22-24$ & $\begin{array}{l}\text { Лише за } \\
\text { акромегалії }\end{array}$ & $\begin{array}{l}\text { 65\% пацієнтів із } \\
\text { комплексом Карні }\end{array}$ & $\begin{array}{l}\text { Акромегалія, серцеві та шкірні } \\
\text { міксоми, первинна пігментна } \\
\text { хвороба надниркових залоз } \\
\text { в пігментні ураження шкіри } \\
\text { та слизових (комплекс Карні) }\end{array}$ & $\begin{array}{l}\text { Соматотропінома } \\
\text { або гіперплазія }\end{array}$ \\
\hline$S D H x$ & $\begin{array}{l}\text { SDHA } \\
\text { 5p15.33 } \\
\text { SDHB1p36.13 } \\
\text { SDHC1q23.3 } \\
\text { SDHD11q23.1 }\end{array}$ & Зрідка & Зрідка & $\begin{array}{l}\text { Акромегалія та парагангліома/ } \\
\text { феохромоцитома (ЗР синдром) }\end{array}$ & Соматотропінома \\
\hline GPR101 & $X q 26.3$ & 1.6 & $0-4,4 \%$ & $\begin{array}{l}\text { Х-зчеплений акрогігантизм, дуже } \\
\text { ранній початок гігантизму }\end{array}$ & $\begin{array}{l}\text { Соматотропінома } \\
\text { або гіперплазія }\end{array}$ \\
\hline GNAS & $20 q 13.3$ & $\begin{array}{l}\text { Лише за } \\
\text { акромегалії }\end{array}$ & $40 \%$ & $\begin{array}{l}\text { Спорадична акромегалія або } \\
\text { синдром МакК'юна - Олбрайта }\end{array}$ & $\begin{array}{l}\text { Соматотропінома } \\
\text { або гіперплазія }\end{array}$ \\
\hline
\end{tabular}

Дослідження в даній сфері стали можливими завдяки геномним технологіям, які дозволяють цілком секвенувати людський геном (визначити послідовність нуклеодидів і, відповідно, генів) або провести генотипування (GWAS genome-wide association study) - ідентифікувати тисячі асоціацій між генетичними варіантами та хворобами або особливостями фенотипу, а також створити карти унікальних варіантів певних генів у межах популяцій. Дана технологія є ідеальною платформою для оцінки відомих маркерів у геномі людини, що дає змогу дослідникам знайти однонуклеотидні поліморфізми (SNP) і більші структурні зміни в геномі конкретної людини або популяції загалом [15].

Підгрунтям для таких досліджень був найбільший в історії міжнародний проект у галузі біології «Геном людини», що тривав понад 10 років і дав змогу ідентифікувати послідовність нуклеотидів у геномі Homosapiens, це близько 20-25 тисяч генів, унаслідок чого було створено референтний геном людини (зразковий) [16].

Наразі в Україні дана сфера медичних досліджень перебуває в зародковому стані, і ство- рення генетичних карт українців, надто з рідкісними хворобами, дасть можливість глибшого вивчення їх тригерів і можливостей для лікування.

Мета дослідження - провести повногеномний пошук асоціацій геному 5 хворих на акромегалію для виявлення відомих мутацій у генах, асоційованих із даним захворюванням, і суміжних ділянках. Створити першу референтну геномну базу пацієнтів з акромегалією української популяції для подальшого вивчення причин виникнення цієї хвороби та впровадження персоніфікованого лікування згідно з генетичним профілем.

Новизна дослідження - повногеномний пошук асоціацій (GWAS) серед українців зроблено вперше. Українська популяція жодного разу не брала участі в повногеномних дослідженнях, проте в усьому світі такі проекти є підгрунтям і передовою технологією встановлення причин захворювань, їх частоти в різних популяціях людей і винаходу нових методів терапії [15]. Прикладами даного типу досліджень є міжнародний проект «1000 геномів», який встановив карту генетичних варіацій у 14 світових по- 
пуляціях людей [17]. Також наразі різні країни створюють національні геномні програми 3 метою встановлення генетичних особливостей власного народу, його походження, генетичного профілю поширених і рідкісних захворювань. Такі проекти вже існують в Ісландії, Ірландії, Англії, Японії, Фінляндії, Швеції та Голландії [18-20].

\section{Матеріал і методи}

До дослідження включено 5 пацієнтів 3 акромегалією, із них 3 чоловіки та 2 жінки, які перебувають на обліку в ендокринологічному відділенні Закарпатської обласної клінічної лікарні ім. А. Новака. Усі пацієнти підписали інформовану добровільну згоду на аналіз та обробку даних, отриманих у ході дослідження їхнього біологічного матеріалу. Критерієм включення була наявність встановленого, клінічно та лабораторно підтвердженого діагнозу акромегалії, підтвердженої МРТ макроаденоми гіпофіза. Критерієм виключення була наявність тяжких запальних захворювань ротової порожнини, які перешкоджали правильному забору зразка слини. Профіль пацієнтів: середній вік становив 43 роки. Із них двом пацієнтам проведено транскраніальне видалення пухлини, одному - транссфеноїдальне видалення, двох пацієнтів не оперували. Один пацієнт хворіє на цукровий діабет 2-го типу, резистентний до мультикомпонентного лікування, включаючи інсулінотерапію аналоговими формами та неконтрольовану артеріальну гіпертензію. Усі пацієнти мають активну форму акромегалії, у тому числі поопераційні рецидиви, та отримують терапію пролонгованими аналогами соматостатину.

Матеріалом для дослідження була слина, зібрана в стандартний контейнер із буферним розчином. Генотипування проведено за допомогою Infinium Global Screening Array-24 Kit, Illumina $^{\circledR}$. Дана технологія наразі дозволила ідентифікувати 638466 однонуклеотидних поліморфізмів із точністю 99,9\% у кожному досліджуваному геномі.

Отримані дані генотипування проаналізовано за допомогою мови програмування Python інтерпретованої об'єктно-орієнтованої мови програмування високого рівня із суворо динамічною типізацією [21]. Дану мову програ- мування було застосовано в поєднанні 3 програмними бібліотеками PANDAS i SciPy. Частину аналізу проведено за допомогою Python PLINK - безкоштовного, часто застосовуваного, вільно доступного набору інструментів для аналізу повногеномних асоціацій [22].

\section{Результати та обговорення}

Генотипування було вдалим у 4 пацієнтів, один зразок був неякісним за кількістю виділеної ДНК.

Використана панель генотипування дозволила ідентифікувати 154 однонуклеотидні поліморфізми в генах, скомпільованих як асоційовані з акромегалією (табл. 2). Із них 141 ОНП були однаковими в 4 пацієнтів і відповідали референтному геному людини.

Пацієнти різнилися за 8 варіантами нуклеотидів, причому 3 варіанти не було ідентифіковано (неточність технології). Дані порівняння наведено в таблиці 3.

Частоти даних варіантів у різних досліджених популяціях наведено в таблиці 4.

Із наведених таблиць видно, що ОНП rs34330 у гені $C D K N 1 B$ відповідає UTR5 (нетрансльована ділянка або лідерна послідовність) - некодованому відрізку мРНК, розташованому відразу після кеп-ділянки. Ця ділянка може брати участь в ефективності трансляції. За даним ОНП два пацієнти були гомозиготними (CC) та один - гетерозиготним (CT) за альтернативною алеллю, частота якої у світі становить $66,1 \%$, в європейській популяції - 75,0\% за даними проекту 1000 геномів». Її досить висока частота може свідчити про доброякісний характер, проте потенційне функціональне їі значення наразі не описано. Натомість мутації

таблиця 2. Результати генотипування

\begin{tabular}{lll}
\hline $\begin{array}{l}\text { Кількість ОНП } \\
\text { у панелі }\end{array}$ & $\begin{array}{l}\text { Кількість однакових } \\
\text { Онп у } 4 \text { пацієнтів }\end{array}$ & Ген \\
\hline 3 & 3 & AIP1 \\
71 & 70 & MEN1 \\
7 & 5 & CDKN1B \\
0 & 0 & PRKARIA \\
13 & 13 & PRKARIA \\
28 & 25 & PRKARIB \\
13 & 9 & PRKARIC \\
17 & 16 & PRKARID \\
2 & 0 & GPR101 \\
0 & 0 & GNAS \\
\hline
\end{tabular}


Оригінальні дослідження

таблиця 3. Порівняльна характеристика пацієнтів за варіантами нуклеотидів

\begin{tabular}{|c|c|c|c|c|c|c|c|c|c|}
\hline \multirow[t]{2}{*}{ ОНП } & \multirow{2}{*}{$\begin{array}{l}\text { Позиція } \\
\text { на хромосомі }\end{array}$} & \multirow[t]{2}{*}{ Хромосома } & \multicolumn{4}{|c|}{ Пацієнти } & \multirow{2}{*}{$\begin{array}{l}\text { Референтний } \\
\text { варіант }\end{array}$} & \multirow{2}{*}{$\begin{array}{l}\text { Альтернатив- } \\
\text { ний варіант }\end{array}$} & \multirow[t]{2}{*}{ Ген } \\
\hline & & & 1 & 2 & 3 & 4 & & & \\
\hline rs34330 & 12870695 & 12 & CC & CC & $\mathrm{CT}$ & $\mathrm{TT}$ & $\mathrm{T}$ & $C$ & CDKN1B \\
\hline rs2066827 & 12871099 & 12 & GG & GT & $\mathrm{TT}$ & $\mathrm{TT}$ & $\mathrm{T}$ & G & CDKN1B \\
\hline rs33927012 & 17354297 & 1 & AA & AA & AA & $A G$ & $A$ & G & $\mathrm{SDHB}$ \\
\hline rs2647158 & 17361781 & 1 & $A A$ & AA & AA & $A G$ & $A$ & G & SDHB \\
\hline rs74127632 & 161305625 & 1 & $A A$ & $A G$ & $\mathrm{AA}$ & $\mathrm{AA}$ & $A$ & G & SDHC \\
\hline rs11585941 & 161312656 & 1 & $A G$ & AA & $\mathrm{AA}$ & $\mathrm{AA}$ & $A$ & G & SDHC \\
\hline rs4600063 & 161333191 & 1 & AA & $A G$ & AA & $\mathrm{AA}$ & A & G & $\mathrm{SDHC}$ \\
\hline
\end{tabular}

таблиця 4. Частоти варіантів нуклеотидів у різних популяціях

\begin{tabular}{|c|c|c|c|c|c|c|}
\hline ОНП & $\begin{array}{l}\text { Функція } \\
\text { ділянки гена }\end{array}$ & $\begin{array}{l}\text { Замінна } \\
\text { амінокислота }\end{array}$ & $\begin{array}{l}\text { Усереднена } \\
\text { частота } \\
\text { У світі згідно } \\
\text { з } 1000 \text { геномів }\end{array}$ & $\begin{array}{l}\text { Частота } \\
\text { в європейській } \\
\text { популяції згідно } \\
\text { з } 1000 \text { геномів }\end{array}$ & $\begin{array}{l}\text { Fathmm-MKL_} \\
\text { coding* }\end{array}$ & $\underset{* *}{\text { MetaSVM_pred }}$ \\
\hline rs34330 & UTR5 & - & 0,661741 & 0,75 & - & - \\
\hline rs2066827 & екзонна & несинонімічна & 0,359225 & 0,24 & шкідлива & $\begin{array}{l}\text { потенційно } \\
\text { шкідлива }\end{array}$ \\
\hline rs33927012 & екзонна & несинонімічна & 0,00938498 & 0,02 & шкідлива & шкідлива \\
\hline rs2647158 & інтронна & - & 0,236222 & 0,2 & - & - \\
\hline rs74127632 & інтронна & - & 0,163339 & 0,05 & - & - \\
\hline rs11585941 & інтронна & - & 0,133786 & 0,113 & - & - \\
\hline rs4600063 & UTR3 & - & 0,16893 & 0,049 & шкідлива & $\begin{array}{l}\text { потенційно } \\
\text { шкідлива }\end{array}$ \\
\hline
\end{tabular}

Примітки: * - функціональний аналіз методом прихованих моделей Маркова - система прогнозу функціональних наслідків кодуючих і некодуючих ділянок; ** - метааналітична система методу опорних векторів для оцінки ефекту мутації.

в гені $C D K N 1 B$ (супресор-онкоген), який кодує білок-інгібітор циклін-залежної кінази 1В, можуть призводити до розвитку MEN4. Дана мутація потребує верифікації на функціональну здатність білка, оскільки його активність залежить від посттрансляційних змін [23].

ОНП rs2066827 у тому ж гені $C D K N 1 B$ знаходиться в екзонній (кодуючій) ділянці. Один із 4 пацієнтів був гомозиготним за альтернативною алеллю (ТT), один - гетерозиготним (GT), двоє - гомозиготними за референтною алеллю (ТT). Частота альтернативної алелі у світі становить $35 \%$, в Свропі - 24\% за даними проекту «1000 геномів». Вона $є$ несинонімічною, тобто призводить до зміни амінокислоти в протеїні. Двома різними аналітичними системами іï описано як шкідливу або потенційно шкідливу. Вона також потребує подальшої верифікації щодо функціонального стану білка, кодованого геном $C D K N 1 B$.

ОНП rs33927012 знаходиться в екзонній ділянці гена $S D H B$. Один пацієнт був гетерозиготним за альтернативною алеллю (AG), троє пацієнтів - гомозиготними за референтною алеллю. Дана альтернативна алель є надзви- чайно рідкісною у світовій популяції, її частота становить $0,9 \%$, у європейській популяції - $2 \%$ за даними проекту «1000 геномів». Її описано як шкідливу двома аналітичними системами. Мутації гена $S D H B$ призводять до структурних змін у білку SDH - сукцинілдегідрогеназі, яка відіграє ключову роль у циклі Кребса та окисному фосфорилюванні. Даний ген є тумор-супресор-геном, і його мутації спричиняють $3 \mathrm{P}$ синдром [24]. Ця мутація в пацієнта потребує подальшого вивчення шляхом визначення активності сукцинілдегідрогенази та діагностичного пошуку наявності парагангліоми та/або феохромоцитоми, оскільки даний пацієнт хворіє на тяжку артеріальну гіпертензію та цукровий діабет.

Також у генах $S D H B, S D H C$ досліджують три інтронні (нетранскрибовані) мутації (див. табл. 3, 4), для яких описано частоту, але не функцію. Глибокі інтронні мутації потребують подальшого вивчення, оскільки є дані про їх зв'язок із деякими захворюваннями [25].

ОНП rs4600063 визначається в ділянці гена $S D H C$, яка відповідає за UTR-3 ділянку - нетрансльовану ділянку, розташовану після 
стоп-кодону. Ці ділянки часто відповідають за регуляторні функції та пострансляційні зміни білка. Ген $S D H C$ відповідає за С-субодиницю сукцинілдегідрогенази [26]. Один пацієнт був гетерозиготним(AG) за альтернативною алеллю, троє - гомозиготними за референтною. Дана мутація є абсолютно не вивченою, для неї не розраховано частоти в популяціях. Вона потребує подальшого аналізу та вивчення функціонального статусу протеїну.

\section{Висновки}

Пацієнти зі спорадичними формами акромегалії є надзвичайно генетично гетерогенними та не мають єдиної, однакової для всіх мутації, яка б відповідала за утворення соматотропіном гіпофіза. Нам вдалося знайти три екзонні загрозливі та потенційно шкідливі мутації в генах $C D K N 1 B$ і $S H D B$, які виявляються в пацієнтів 3 ендокринними синдромами. Вони потребують подальшої верифікації молекулярно-генетичними та гормональними методами, оскільки можуть свідчити, що в пацієнта з акромегалією можуть бути й інші, приховані ендокринні неоплазії (феохромоцитома, парагангліома, пухлини прищитоподібних і підшлункової залози), або він має ризик їх розвитку, що потребує поглибленого обстеження та ретельного спостереження такого пацієнта. Метод повногеномного генотипування є потужним інструментом у виявленні деяких причин рідкісних захворювань, які однозначно потребують персоніфікованого медичного підходу. Проте з огляду на лише часткове «покриття» геному в даному методі та особливості захворювання є сенс використання секвенування екзонів або повногеномного секвенування для пошуку та ідентифікації генетичної причини виникнення цих захворювань. Наразі даний вид досліджень стрімко розвивається у світі, його вартість відчутно знижується, отже, слід розглянути можливість застосування даних досліджень у рутинній медичній практиці для індивідуального та точного підходу до діагностики захворювань.

\section{Науково-практичне використання}

Отримані дані є першою генетичною базою даних пацієнтів з акромегалією в Україні й можуть бути використаними для порівняння та розрахунків частот різних асоційованих з акромегалією мутацій у популяції українців у майбутньому.
Також виявлені в окремих пацієнтів мутації дозволять лікарям провести спрямований діагностичний пошук ознак інших ендокринних пухлин, імовірність яких є високою за наявності певних ідентифікованих мутацій.

\section{Список використаної літератури}

1. Veldhuis JD, Iranmanesh A, Erickson D, Roelfsema F, Bowers C. Lifetime regulation of growth hormone $(\mathrm{GH})$ secretion. In: Handbook of Neuroendocrinology. Elsevier; 2012. Chapter 10, p. 237-57.

2. Sotos JF, Argente J. Overgrowth disorders associated with tall stature. Adv Pediatr. 2008;55:213-54.

3. Burton T, Le Nestour E, Neary M, Ludlam WH. Incidence and prevalence of acromegaly in a large US health plan database. Pituitary. 2016 Jun;19(3):262-7.

4. Xekouki P, Azevedo M, Stratakis CA. Anterior pituitary adenomas: inherited syndromes, novel genes and molecular pathways. Expert Rev Endocrinol Metab. 2010 Sep 1;5(5):697-709.

5. Daly AF, Vanbellinghen JF, Khoo SK, Jaffrain-Rea ML, Naves LA Guitelman MA, et al. Aryl hydrocarbon receptor-interacting protein gene mutations in familial isolated pituitary adenomas: analysis in 73 families. J Clin Endocrinol Metab. 2007 May;92(5):1891-6.

6. Hernández-Ramírez LC, Gabrovska P, Dénes J, Stals K, Trivellin G Tilley D, et al. Landscape of familial isolated and young-onset pituitary adenomas: prospective diagnosis in AIP mutation carriers. J Clin Endocrinol Metab. 2015 Sep;100(9): E1242-54.

7. Trivellin G1, Daly AF, Faucz FR, Yuan B, Rostomyan L, Larco DO, et al. Gigantism and acromegaly due to Xq26 microduplications and GPR101 mutation. N Engl J Med. 2014 Dec 18;371(25):2363-74.

8. Salpea P, Stratakis CA. Carney complex and McCune Albright syndrome: an overview of clinical manifestations and human molecular genetics. Mol Cell Endocrinol. 2014 Apr 5;386 (12):85-91.

9. Horvath A, Stratakis CA. Clinical and molecular genetics of acromegaly: MEN1, Carney complex, McCune Albright syndrome, familial acromegaly and genetic defects in sporadic tumors. Rev Endocr Metab Disord. 2008 Mar;9(1):1-11.

10. Stratakis CA, Tichomirowa MA, Boikos S, Azevedo MF, Lodish M, Martari M, et al. The role of germline AIP, MEN1, PRKAR1A CDKN1B and CDKN2C mutations in causing pituitary adenomas in a large cohort of children, adolescents, and patients with genetic syndromes. Clin Genet. 2010 Nov;78(5):457-63.

11. Marinoni I, Pellegata NS. p27kip1: a new multiple endocrine neoplasia gene? Neuroendocrinology. 2011;93(1):19-28.

12. Agarwal SK, Mateo CM, Marx SJ. Rare germline mutations in cyclin-dependent kinase inhibitor genes in multiple endocrine neoplasia type 1 and related states. J Clin Endocrinol Metab. 2009 May;94(5):1826-34.

13. Mai PL, Korde L, Kramer J, Peters J, Mueller CM, Pfeiffer S, et al. A possible new syndrome with growth-hormone secreting pituitary adenoma, colonic polyposis, lipomatosis, lentigines and renal carcinoma in association with familial testicular germ cell malignancy: A case report. J Med Case Rep. 2007 Mar 28;1:9.

14. Faucz FR, Horvath AD, Azevedo MF, Levy I, Bak B, Wang Y, et al. Is IGSF1 involved in human pituitary tumor formation? Endocr Relat Cancer. 2015 Feb;22(1):47-54.

15. Visscher PM, Brown MA, McCarthy MI, Yang J. Five years of GWAS discovery. Am J Hum Genet. 2012 Jan 13;90(1):7-24.

16. Burke W, Khoury MJ, Stewart A, Zimmern RL; Bellagio Group. The path from genome-based research to population health: development of an international public health genomics network. Genet Med. 2006 Jul;8(7):451-8.

17. 1000 Genomes Project Consortium, Abecasis GR, Auton A, Brooks LD, DePristo MA, Durbin RM, et al. An integrated map of genetic variation from 1,092 human genomes. Nature. 2012 Nov 1;491(7422):56-65

18. Palsson G, Rabinow P. Iceland: the case of a national human genome project. Anthropol Today. 1999 Oct;15(5):14-8. 
Оригінальні дослідження

19. Haga H, Yamada R, Ohnishi Y, Nakamura Y, Tanaka T. Gene-based SNP discovery as part of the Japanese Millennium Genome Project: identification of 190.562 genetic variations in the human genome Single-nucleotide polymorphism. J Hum Genet. 2002;47(11):605-10.

20. Ripke S, O'Dushlaine C, Chambert K, Moran JL, Kähler AK, Akterin S, et al. Genome-wide association analysis identifies 13 new risk loci for schizophrenia. Nat Genet. 2013 Oct;45(10):1150-9.

21. Guido van Rossum Fred L. Drake, Jr., editor. Python reference manual. 1995

22. Purcell S, Neale B, Todd-Brown K, Thomas L, Ferreira MA, Bender D, et al. PLINK: a tool set for whole-genome association and population-based linkage analyses. Am J Hum Genet. 2007 Sep;81(3):559-75.

23. Georgitsi M, Raitila A, Karhu A, van der Luijt RB, Aalfs CM, Sane T, et al. Germline CDKN1B/p27Kip1 mutation in multiple endocrine neoplasia. J Clin Endocrinol Metab. 2007 Aug;92(8):3321-5.

24. Kim E, Rath EM, Tsang VH, Duff AP, Robinson BG, Church WB et al. Structural and functional consequences of succinate dehydrogenase subunit B mutations. Endocr Relat Cancer. 2015 Jun;22(3):387-97.

25. Mendes de Almeida R, Tavares J, Martins S, Carvalho T, Enguita FJ, Brito D, et al. Whole gene sequencing identifies deepintronic variants with potential functional impact in patients with hypertrophic cardiomyopathy. PLoS One. 2017 Aug 10;12(8): e0182946.

26. Kuersten S, Goodwin EB. The power of the 3' UTR: translational control and development. Nat Rev Genet. 2003 Aug;4(8):626-37.

\section{Полногеномный поиск ассоциаций у пациентов с акромегалией в украинской популяции}

\section{О.Т. Олексик, Х.М. Щубелка, В.В. Волфсбергер \\ Ужгородский национальный университет, г. Ужгород}

Резюме. Гипофиз-зависимый избыток СТГ может быть генетическим заболеванием (в литературе описан ряд мутаций, которые приводят к изолированному избытку гормона роста) или как симптом в составе синдромного заболевания. Цель - провести полногеномный поиск ассоциаций генома больных акромегали ей для выявления известных мутаций в генах, ассоциированных с данным заболеванием, и смежных участках. Создать первую референтную геномную базу пациентов украинской популяции с акромегалией для дальнейшего изучения причин возникновения этой болезни и внедрения персонифицированного лечения согласно с генетическим профилем. Результаты. Проведен полногеномный поиск ассоциаций в геноме 5 пациентов с акромегалией с целью выявления известных мутаций в генах, ассоциированных с данным заболеванием, и смежных участках. Использованная панель генотипирования позволила идентифицировать 154 однонуклеотидных полиморфизма в генах, описанных ранее как ассоциированные с акромегалией. Один пациент оказался гетерозиготен по альтернативной аллели (AG) OHП rs33927012 гена SDHB. Данная альтернативная аллель является чрезвычайно редкой в мировой популяции (0,9\%, в европейской популяции -
2\%). Она описана как вредная двумя аналитическими системами. Мутации гена SDHB приводят к структурным изменениям в белке SDH (сукцинил-зависимая дегидрогеназа), который играет ключевую роль в цикле Кребса и окислительном фосфорилировании. Данный ген является тумор-супрессор геном, и его мутации вызывают 3Р синдром (акромегалия, феохромоцитома, параганглиома). Также найдены мутации в генах SDHC, CDKN1B, уникальные для некоторых пациентов из данной выборки. Выводы. Обнаружены три экзонные угрожающие и потенциально вредные мутации в генах CDKN1B и SHDB, которые выявляются у пациентов с эндокринными синдромами.

Ключевые слова: акромегалия, геном, мутации.

\section{Genome wide search for associations in patients with acromegaly in the Ukrainian population}

\author{
O.T. Oleksyk, K.M. Shchubelka, W.W. Wolfsberger \\ Uzhhorod National University
}

Abstract. Pituitary-dependent excess of $\mathrm{GH}$ may be a genetic disease, the literature describes a number of mutations that lead to an isolated excess of growth hormone, or as a symptom in a syndromic disease. The goal is to conduct a genome-wide search for associations of the patients with acromegaly genome to identify known mutations in the genes associated with this disease in adjacent sites. Create the first reference genomic base of Ukrainian patients with acromegaly to further study the causes of this disease and the introduction of personalized treatment in accordance with the genetic profile. Results. This article presents the results of a genome-wide search of the genome of 5 patients with acromegaly. The genotyping panel we used allowed us to identify 154 single-nucleotide polymorphisms in the genes that were previously described as associated with acromegaly. One patient is heterozygous for the alternative allele (AG) of SNPs rs33927012 of SDHB gene. This alternative allele is extremely rare in the world population $(0.9 \%$, in the European population $2 \%)$. It is described as harmful by two analytical systems. Mutations in the SDHB gene lead to structural changes in the SDH protein (succinyl-dependent dehydrogenase), which plays a key role in the Krebs cycle and oxidative phosphorylation. This gene is a tumor suppressor gene and its mutations cause 3P syndrome (acromegaly, pheochromocytoma, paraganglioma). We also found mutations in the genes SDHC, CDKN1B unique to some patients from this sample. Conclusion. Three exon threatening and potentially harmful mutations were found in the genes CDKN1B and SHDB, which are detected in patients with endocrine syndromes.

Keywords: acromegaly, genome, mutations. 